\title{
Obywatelstwo europejskie w świetle Karty Praw Podstawowych
}

DOI: $10.35757 / C I V .2010 .12 .02$

Celem artykułu jest analiza rozdziału V Karty Praw Podstawowych dotyczącego praw obywateli. Będzie ona poprzedzona wprowadzeniem historycznym dotyczacym kategorii obywatelstwa. Następnie zostaną zrekonstruowane możliwości logiczne, jakie się wyłaniaja $z$ przyjętych w Karcie Praw Obywatelskich, a następnie wizja obywatelstwa i wizja Unii Europejskiej, jaka kryje się za tymi regulacjami.

\section{Pojęcie obywatelstwa}

Zacznijmy od nakreślenia historyczno-filozoficznego kategorii obywatelstwa oraz jej ważności współcześnie. W historii występuja przynajmniej dwa typy budowania obywatelskiej więzi politycznej. Pierwszy odnosi się do obywatelstwa opartego na prawach, stricte politycznego, w którym język, kultura czy więzy krwi nie stanowia podstawy do zawiązania wspólnoty politycznej, a głównym elementem integrującym jest zamieszkiwanie na określonym terytorium - więź prawna i administracyjna narzucona oddolnie lub odgórnie przez władzę. Tego typu konstrukcję obywatelstwa możemy

Rafat Wonicki - doktor filozofii, adiunkt w Instytucie Studiów Politycznych Polskiej Akademii Nauk w Warszawie oraz w Instytucie Filozofii Uniwersytetu Warszawskiego. 
odnaleźć w Imperium Rzymskim, w rozważaniach Johna Locke’a czy Thomasa Hobbesa, w pismach ojców założycieli Stanów Zjednoczonych. Drugi typ odnosi się do XIX-wiecznej koncepcji narodu i obywatelstwa narodowego opartego właśnie na kulturze, języku czy więzach krwi. Niezależnie od tego, jak w teorii i praktyce przebiegało kształtowanie się tożsamości państwowej i poczucia przynależności do danej wspólnoty politycznej, to było ono ograniczone - poza małymi wyjątkami teorii kosmopolitycznych stoików czy teorii ogólnoludzkiej wspólnoty chrześcijańskiej - do suwerennego państwa $z$ niezależna władza, zwłaszcza po pokoju westfalskim, który ukształtował i utrwalił podział na terytorialnie suwerenne państwa. Taki system trwał w Europie aż do końca drugiej wojny światowej, do momentu narodzin Unii Europejskiej oraz do czasu nasilenia się tendencji globalizacyjnych. Po drugiej wojnie do kwestii obywatelstwa państwowego dołączono i wyeksponowano nowy wątek, który pojawił się $\mathrm{w}$ dziejach nowożytnych wraz $\mathrm{z}$ rewolucja francuska, mianowicie prawa człowieka. Stanowiły one legitymizację dla ograniczenia władzy państwa. $Z$ kolei one same moga być chronione jedynie politycznie. Przed druga wojna światowa to państwa w ramach swoich suwerennych rozstrzygnięć prawych zapewniały swoim obywatelom ochronę ich praw "naturalnych”, niezależnie od tego, jakie prawa uznawano za naturalnie przyrodzone człowiekowi i podlegajace ochronie. Dopiero po wojnie, wraz $z$ próba ochrony przed jej katastrofami i okropieństwami, prawa człowieka stały się przedmiotem ochrony międzynarodowej. Zgromadzenie Ogólne Organizacji Narodów Zjednoczonych uchwaliło w 1948 roku Powszechna Deklarację Praw Człowieka i Obywatela. ONZ nie udało się jednak zapewnić całkowicie skutecznej ochrony praw człowieka, jedna $z$ przyczyn był $z$ pewnościa historyczny kontekst powstania tej organizacji oraz jej cel. To zwycięskie państwa, nie wszystkie będąc demokracjami, postanowiły powołać do życia Powszechna Deklarację. Jednak zapisane w niej prawa miały być zapewnione przez suwerenne państwa $\mathrm{w}$ miarę ich możliwości. Kolejna próbę ochrony praw człowieka podjęto w związku $z$ uchwa- 
leniem w 1950 roku w Rzymie Europejskiej Konwencji o Ochronie Praw Człowieka i Podstawowych Wolności, w której państwa poddaja się dobrowolnie pod kontrolę Europejskiego Trybunału Praw Człowieka w Strasburgu w zakresie, na jaki wcześniej się zgodziły (chodzi głównie o ochronę obywateli przed władzą państwowa oraz potwierdzenie ich prawa do wolności myśli, sumienia i wyznania, zakazu tortur, gwarancji sprawiedliwego procesu itp.) ${ }^{1}$. Jednocześnie wraz z rozwojem Wspólnoty i jej uspójnieniem rosło znaczenie praw człowieka, a tym samym wzrastała ranga zapisów Konwencji oraz potrzeba nadania Wspólnocie jednorodnych standardów gwarantujacych te prawa, czego Konwencja nie była już w stanie zapewnić, ponieważ nie była częścią traktatów składających się na Unię. W wyniku tego procesu doszło do utworzenia odrębnego, uwspółcześnionego dokumentu, jakim jest Karta, wydobywającego $z$ dotychczasowych traktatów zapisy dotyczace praw człowieka i obywatela. Miało to przede wszystkim na celu ujednolicenie i zebranie w jednym miejscu przepisów, które Trybunał Sprawiedliwości i tak w praktyce przyjmuje jako podstawę w swoich orzeczeniach ${ }^{2}$.

Karta Praw Podstawowych jest zatem wyrazem tendencji konsolidacyjnych i ma na celu "lepsze” uwidocznienie podstaw aksjologicznych Unii, czyli „podstawowych” praw człowieka. Sposobem, $\mathrm{w}$ jaki ma się to dokonać, jest podniesienie statusu praw podstawowych do rangi praw obywatelskich. Pytanie, które się rodzi $\mathrm{w}$ tym momencie, dotyczy tego, jaki model Unii będzie najlepiej

\footnotetext{
1 Por. Europejska Konwencja o Ochronie Praw Człowieka i Podstawowych Wolności (www. informacjapubliczna.org.pl/pliki/Europejska\%20Konwencja\%20\%Oochronie\%20Praw\%20 Człowieka.pdf).

2 Por. A. Nogal: Karta Praw Podstawowych Unii Europejskiej, „Civitas. Studia z Filozofii Polityki” 2002, nr 6, eadem: Ponad prawem narodowym. Konstytucyjne idee Europy, Instytut Studiów Politycznych PAN, Warszawa 2009, s. 113-136. Nie zagłębiając się w porównania tych dwóch dokumentów, należy nadmienić, że Karta jest treściowo o wiele szersza od Konwencji, na przykład reguluje sprawy etyki medycznej (zakaz klonowania ludzi w celach rozrodczych). Novum stanowią artykuły dotyczące wyrównywania nierówności między mężczyznami i kobietami oraz artykuły socjalne gwarantujące pomoc dla osób starszych, niepełnosprawnych czy dzieci. Karta jest zatem wyrazem pewnego większego projektu politycznego Unii, którego jednym $z$ elementów jest obywatelstwo.
} 
stał na straży tych praw. Aby dopowiedzieć na to pytanie, należy prześledzić zapisy Karty Praw Podstawowych dotyczace obywatelstwa.

\section{Obywatelstwo europejskie?}

Kwestię obywatelstwa europejskiego reguluje w Karcie osiem artykułów:

1. Prawo głosowania i kandydowania w wyborach do Parlamentu Europejskiego - każdy obywatel zamieszkały w jednym $z$ państw członkowskich posiada bierne i czynne prawo wyborcze jako obywatel Unii do uczestniczenia w strukturach Unii.

2. Prawo głosowania i kandydowania w wyborach lokalnych, które potwierdza „podwójne” obywatelstwo mieszkańców państw członkowskich.

3. Prawo do dobrej administracji, które jest powieleniem zapisów znajdujących się w większości konstytucji państw członkowskich.

4. Prawo dostępu do dokumentów, którego celem jest transparentność i jawność podejmowania decyzji w Unii.

5. Rzecznik Praw Obywatelskich - każdy obywatel Unii może wnieść skargę do Parlamentu Europejskiego.

6. Prawo petycji - każdy obywatel Unii ma prawo formułowania petycji do Parlamentu Europejskiego mieszczaccych się w zakresie działania Unii.

7. Swoboda przemieszczania się i pobytu - dotyczy swobodnego poruszania się głównie osób $\mathrm{w}$ wieku produkcyjnym oraz studentów.

8. Opieka dyplomatyczna i konsularna - każdy obywatel Unii, przebywając na terytorium państwa trzeciego, gdzie państwo, którego jest obywatelem, nie jest reprezentowane, może korzystać $z$ opieki władz dyplomatycznych i konsularnych każdego państwa członkowskiego ${ }^{3}$.

3 Karta Praw Podstawowych (www.kartaprawpodstawowych.org.pl). 
Na podstawie wyżej wymienionych punktów zawartych w Karcie $i$ dotyczacych obywatelstwa możemy zrekonstruować kilka płaszczyzn, na jakich ma się opierać i funkcjonować przyszłe obywatelstwo europejskie:

- tożsamościowa: umożliwiająca budowanie zależności na poziomie „europejskim”;

- instytucjonalna: dająca możliwość wyrażania swojej europejskości (na przykład prawo do głosowania);

- prawna: dotyczaca zakresu praw obywatelskich.

Wydaje się, że budowa „europejskiego domu” lub - jak tytułuje jedna ze swych ksiażek Jeremy Rifkin - spełnienie „europejskiego marzenia" sa zaawansowane. Najbardziej widoczny jest wymiar instytucjonalny i prawny Unii. Przeciwnicy Unii wytykaja jej nawet, że jest za bardzo zbiurokratyzowana. Twór, jaki stanowi, jest wielowarstwowy - kolejne traktaty, komisje, sfery obejmujące swoim działaniem jedynie niektóre państwa członkowskie, tak jak w wypadku wspólnej waluty, sprawiaja, że dla przeciętnego obywatela Unia jawi się jako niezrozumiała. Sprawy nie ułatwia fakt, że większość mechanizmów dotyczących podejmowania decyzji ma charakter dyskretny, negocjacyjny, niejawny. Zanim jednak dokładniej omówimy wyżej wymienione, splecione ze soba płaszczyzny czy wymiary „europejskiego obywatelstwa”, wyróżnijmy kilka możliwych do pomyślenia modeli obywatelstwa, biorac pod uwage dwa czynniki: obywatelstwo państwowe i obywatelstwo europejskie:

1) obywatelstwo europejskie tożsame zakresowo $z$ obywatelstwem państwowym;

2) obywatelstwo europejskie węższe zakresowo od obywatelstwa państwowego;

3) obywatelstwo europejskie szersze zakresowo od obywatelstwa państwowego;

4) obywatelstwo europejskie i obywatelstwo państwowe.

Według Karty obywatelem Unii Europejskiej jest każda osoba mająca obywatelstwo któregoś $z$ państw członkowskich. Zatem obywatelstwo Unii to przypadek drugi. Przypadek pierwszy byłby brany pod uwage jedynie wtedy, gdyby obywatelstwo Unii prze- 
widywało oprócz praw jakieś obowiązki, próbując oddać w pełni znaczenie i rolę obywatelstwa na poziomie ponadnarodowym. Przypadek trzeci moglibyśmy brać pod uwage jedynie wówczas, gdyby katalog praw wykraczał poza zagadnienia znajdujace się w zakresie obywatelstwa państwowego, ale tak nie jest. Jeśli chodzi o przypadek czwarty, to przyznaję, że nie dostrzegam żadnego elementu wchodzacego w zakres obywatelstwa Unii i nie mającego swojego odpowiednika po stronie obywatelstwa państwowego.

Podstawa obywatelstwa unijnego jest zatem narodowość państwowa osób z państw członkowskich, sam katalog praw podstawowych zaś jest raczej katalogiem formalnym umożliwiajacym obywatelom demokratyczne uczestnictwo w strukturach Unii (prawa wyborcze) oraz pewna transparentność, a co za tym idzie - kontrolę decyzji unijnych (wgląd w dokumenty). Stanowi także instancję odwoławczą i nadzorująca decyzje oraz instytucje na poziomie państwowym (prawo do dobrej administracji czy prawo petycji).

\section{Kłopoty z definicja obywatelstwa zawarta w Karcie}

Mimo szczytnych intencji należy zwrócić uwagę na wieloznaczność zapisów Karty dotyczących obywatelstwa. $Z$ jednej strony sa one wyrazem zgody państw członkowskich na pewną wspólna wizję instytucji ułatwiajacych obywatelom państwa partycypację $\mathrm{w}$ strukturach ponadpaństwowych, $z$ drugiej strony jednak $z$ definicji obywatelstwa wyłączone sa prawa kulturowe czy społeczne, a wiele poszczególnych zapisów ma klauzule, w których niektóre państwa zastrzegaja sobie niestosowanie się do przepisów ogólnych. Ostatecznie więc to od decyzji państw członkowskich ciągle zależy, jakie grupy zyskają obywatelstwo europejskie ${ }^{4}$. Może

\footnotetext{
4 W Traktacie ustanawiajacym Wspólnote Europejska przyznano obywatelom Unii podobne prawa jak w Karcie. Wydaje się jednak, że w dalszym ciagu dość nieczytelne pozostaje samo pojęcie „obywatelstwo europejskie”. Nie jest to już bowiem klasyczna relacja obywatela
} 
to być przyczyna problemów $z$ obywatelstwem dla mieszkańców nie będacych członkami Unii przebywajacych już długo na terenie państwa będącego jej członkiem. Karta w art. 45 ust. 2 pozostawia ta kwestię do regulacji wewnętrznej danego państwa członkowskiego: „Swoboda przemieszczania się i pobytu może zostać przyznana, zgodnie $z$ Traktatem ustanawiajacym Wspólnote Europejska, obywatelom państw trzecich legalnie przebywającym na terytorium Państwa Członkowskiego"5. Jest zatem tak, że państwa moga pozbawić niektóre osoby możliwości wjazdu do swojego kraju, wskazujac $z$ jednej strony na brak środków do życia lub bezpieczeństwo publiczne albo $z$ drugiej strony na możliwość naruszenia ich spójności politycznej i tożsamości kulturowej. W obu przypadkach państwa członkowskie będa wtedy rozumiały zapisy Karty warunkowo i opcjonalnie, otwierajac i zamykajac swoje granice w zależności od tego, jak politycznie zdefiniują relację między prawami człowieka a prawami obywatelskimi. To samo dotyczy tych imigrantów, którzy, choć moga długo mieszkać na terenie danego państwa członkowskiego, sa wykluczeni ze swobody przemieszczania się, uzyskiwania legalnej pracy itp. (odrzucenie to ma najprawdopodobniej podłoże społeczne - wysokie koszty ochrony własnych obywateli jako beneficjentów systemu). Inną odrębna kategorię stanowiliby uchodźcy. To znów od decyzji państw zależy, nawet jeśli podpisały one Konwencję Genewska z 1951 roku dotycząca statusu uchodźców, czy uznają osoby $z$ danego kraju za grupę uchodźców, których życie jest zagrożone, czy też za zwykłych imigrantów, nielegalnych pracowników lub po prostu obcych ${ }^{6}$.

Co więcej, wpisane w Kartę obywatelstwo jest „bierne”, ponieważ nie daje obywatelom żadnej realnej władzy politycznej. Obywatelstwo unijne ma ograniczony status ze względu na prymat prawa państw członkowskich wobec własnych obywateli. Jednocześnie

do władz państwa posiadającego prawa i obowiązki. Na obywateli Unii nie nałożono bowiem żadnych obowiązów.

5 kartaprawpodstawowych.org.pl

6 Por. A. Zieleniec (red.): Obywatelstwo europejskie. Rozważania, przekład P. Florjanowicz i in., Fundacja im. Stefana Batorego, Warszawa 2003. 
pojawiaja się problemy, gdy chcemy przenieść pojęcie obywatelstwa na szczebel ponadpaństwowy i nadać mu wymiar polityczny. Główna przeszkoda jest oczywiście suwerenność państwowa ${ }^{7}$. Gdy myślimy o Unii Europejskiej i obywatelstwie jako silnej demokratycznej partycypacji politycznej, to środkiem do osiagnięcia takiego stanu rzeczy jest ściślejsza integracja polityczna. W tym kierunku zmierzał zarówno odrzucony traktat konstytucyjny, jak i przyjęty traktat lizboński, który jest jedynie nieznacznie zmodyfikowana wersją tego wcześniejszego.

Taka ściślejsza integracja polityczna pociaga za soba jednak ryzyko dekonstrukcji prawnie przyjętego rozumienia suwerenności. Suwerenność państw jest bowiem podstawa prawa międzynarodowego i oznacza przede wszystkim zdolność do niezależnego podejmowania decyzji przez państwo. Oznacza też niezawisłą regulację stosunków wewnatrzpaństwowych. W dobie wzajemnych powiazań globalnego rynku trudno jednak mówić o zupełnym braku ingerencji między państwami w wymiarze ekonomicznym, społecznym czy wreszcie politycznym. Dobrowolne przystapienie do wspólnoty nie znaczy przecież swobody działań w kwestiach regulowanych przez unijne prawo, gdy je zaakceptujemy, choć z pewnością oznacza możliwość zmiany regulacji unijnych od wewnątrz.

\section{W jakim kierunku zmierzamy?}

Zróżnicowane oczekiwania w kwestii roli i kształtu obywatelstwa europejskiego wysuwane przez polityków, naukowców i oby-

\footnotetext{
7 Odnosząc się do zagadnienia suwerenności i obywatelstwa, należy podkreślić, że pojęcia te wiąża się $z$ powstaniem i rozwojem współczesnych państw. Państwa narodowe pojawiły się w Europie w nowożytności. Do takiego, a nie innego rozumienia państw z pewnościa walnie przyczyniły się takie wydarzenia jak wojna trzydziestoletnia czy rewolucja francuska. Do cech konstytutywnych państwa należy terytorium, nad którym patronat sprawuje suwerenna władza. Od rewolucji francuskiej uważa się, że władza czerpie swą legitymizację od ludu - narodu, który zamieszkuje dane terytorium. Bycie obywatelem jest powiązane $z$ byciem członkiem narodu. Relacje międzynarodowe opieraja sie na wzajemnym uznaniu suwerenności państw. Oznacza to, że każde państwo ma pełne prawo do decydowania o swojej polityce zarówno wewnętrznej, jak i zewnętrznej.
} 
wateli pozwalaja lepiej unaocznić problemy, jakie obecnie przed nami stoją. $Z$ punktu widzenia konstytucjonalistów, politologów i filozofów głównym zadaniem jest skonstruowanie spójnego oraz możliwego do zaakceptowania przez wszystkie państwa zbioru reguł składających się na obywatelstwo europejskie, a także kryteriów dostępu do posiadania tego obywatelstwa, co określiłoby zarazem status poszczególnych grup mieszkańców na obszarze Unii Europejskiej. W Karcie Praw Podstawowych na pierwszy plan wychodza formalne zapisy prawne. Wynika to $z$ pewnościa ze zróżnicowania poszczególnych koncepcji obywatelstwa w państwach Unii. Model, który legł u podstaw zapisów o obywatelstwie jest $z$ nastawiony na kompromis, zachowanie ideału suwerenności państwowej oraz ominięcie budowania obywatelstwa na gruncie więzów krwi, miejsca, języka czy przynależności do danego etnosu. Jest to raczej model przypominajacy swymi rozwiazaniami francuski czy amerykański typ obywatelstwa - opartego na patriotyzmie konstytucyjnym, formalnego, oderwanego od koncepcji narodowości etnokulturowej. W tym sensie twórcom Karty nie przyświecało $z$ pewnościa stworzenie jednego państwa, ale raczej rozszerzenie integracji ekonomicznej na obszary polityczne oraz stworzenie właśnie wielonarodowościowej i wielkopaństwowej politycznej wspólnoty, w której obywatele poszczególnych państw nie utożsamiaja się jedynie $z$ państwem, lecz na zasadzie więzów prawnych maja poczucie przynależności również do tej większej wspólnoty. Celem europejskiego obywatelstwa było i jest zatem wytworzenie świadomości ponadnarodowej, która miała uzupełniać, a nie zastępować świadomość i więź narodową̨ ${ }^{8}$ Już samo użycie terminu „obywatelstwo" w Karcie jest wyrazem wiary decydentów w konieczność przeobrażenia Unii oraz chęci zapobieżenia kłopotom integracyjnym $\mathrm{w}$ samej Unii, jakie pojawiły się $\mathrm{w}$ połowie lat dziewięćdziesiątych $\mathrm{XX}$ wieku. W tym wypadku chodzi głównie

\footnotetext{
8 Por. M. Kuniński: Czy Europejczycy moga być dobrymi obywatelami Unii? w: B. Markiewicz, R. Wonicki (red.): Kryzys tożsamości politycznej a proces integracji europejskiej, Wydawnictwo Naukowe Scholar, Warszawa 2006, s. 97-99, 117-119.
} 
o to, że Unia nie była pomyślana jako instytucja demokratyczna, a na drodze jej rozwoju okazało się, że jest coraz bardziej niezbędne, by cieszyła się poparciem społecznym oraz by sama spełniała wymagania przypisywane demokracjom liberalnym. Zatem wprowadzenie kategorii obywatelstwa miało i ma przybliżyć przede wszystkim instytucje Unii obywatelom poszczególnych państw, bez naruszania zasady suwerenności państwowej. Chodziło o to, by obywatele państw członkowskich poczuli się również związani z Unią Europejska, co miało zapewnić sukces integracji i dalszy pomyślny rozwój.

Dyskusja nad zapisami Karty jest również kontynuacja starej debaty o przyszłej politycznej formie Unii i typie obywatelstwa. $Z$ jednej strony mamy bowiem idee oparte na obywatelstwie proceduralnym oraz wspólnej kulturze politycznej i prawnej (na przykład koncepcja Jürgena Habermasa ${ }^{9}$ ), a $z$ drugiej strony klasyczna ideę obywatelstwa oparta na tradycji narodowej i pojęciu suwerenności ludu (na przykład koncepcja Ernsta-Wolfganga Böckenförde ${ }^{10}$ ). Problem polega na tym, że obywatelstwo Unii, zapisane pierwotnie w Traktacie $z$ Maastricht, oparte jest na tych dwóch sprzecznych wobec siebie koncepcjach. W traktacie lizbońskim oraz w Karcie te dwie sprzeczne ze soba tendencje koegzystuja obok siebie i stad też kłopoty ze zdefiniowaniem kierunku rozwoju Unii Europejskiej. $Z$ jednej strony bowiem mamy członków „starej Unii” $z$ jej najważniejszymi graczami, czyli Niemcami i Francja, forsującymi bardziej uniwersalistyczny model ściślejszej integracji politycznej, ale jednocześnie zgodnej $z$ ich interesami narodowymi. $Z$ drugiej zaś strony mamy nowych członków Unii, takich jak Polska, którzy zupełnie inaczej rozumieją politykę - nie jako pewna sferę wspólnych działań wielu współpracujących podsystemów, ale jako międzynarodową działalność państw w ramach większej struktury, w której liczy się siła i przede wszystkim interes państwa.

\footnotetext{
9 Por. J. Habermas: Was braucht Europa eine Verfassung?, „Die Zeit” 2001, nr 27.

${ }^{10}$ Por. E.W. Böckenförde: Państwo prawa $w$ jednoczacej się Europie, przekład P. Kaczorowski, Instytut Studiów Politycznych PAN, Warszawa 2000.
} 


\section{Możliwe rozwiązania}

Nie dążąc absolutnie do przedstawienia wszystkich możliwych dróg, chciałbym wskazać na dwa pomysły, które stanowia interesująca refleksję nad mechanizmami podejmowania decyzji $\mathrm{w}$ Unii. Jednym $\mathrm{z}$ pomysłów na rozwiązanie napięcia wynikającego $z$ odmiennego rozumienia celów, natury i struktur Unii, a także mechanizmów władzy, jest odejście od słownika praw zawartego $\mathrm{w}$ Karcie, co na poziomie politycznym oznacza zrezygnowanie $z$ tworzenia jakiegoś - słabego i formalnego albo silnego i materialnego - obywatelstwa. Niektórzy autorzy - na przykład Jadwiga Staniszkis czy Joseph H.H. Weiler - proponuja wyjście poza binarny paradygmat: konfederacja versus federacja, a zarazem poza opozycję obywatelstwo etniczne - obywatelstwo polityczne oraz spojrzenie na Unię pod zupełnie innym kątem. Jadwiga Staniszkis w książce O władzy $i$ bezsilności proponuje spojrzeć na Unię przez pryzmat pojęcia władzy, która jest rozumiana jako nieliniowy system zarządzania w zglobalizowanej rzeczywistości. W tym wypadku podstawowym narzędziem rządzenia byłyby wypracowane procedury między różnymi, rządzącymi się swoimi odmiennymi racjonalnościami podsystemami, to zaś, co nie byłoby objęte procedurami pozostawiono by do lokalnej samoregulacji. Same procedury byłyby natomiast nieustannie renegocjowane $\mathrm{w}$ ramach systemu administracji unijnej majaccej inicjatywę legislacyjną ${ }^{11}$. To nowe podejście charakteryzowałoby się „dyktatem formy”, a także bardziej elastycznym i dynamicznym podejściem do rozwiąywania problemów politycznych, ekonomicznych czy kulturowych pojawiających

${ }^{11}$ Por. J. Staniszkis: O władzy $i$ bezsilności, Wydawnictwo Literackie, Kraków 2006, s. 200-206. Warto nadmienić, że wielu badaczy, a wśród nich prof. Staniszkis, stwierdza, że po globalnym kryzysie finansów 2007 roku wiele zapisów traktatu lizbońskiego stało się „martwych” lub „papierowych”, a państwa członkowskie i ich przywódcy powrócili do opartej na realizmie politycznym gry w zawieranie sojuszy poza oficjalnymi strukturami Unii. Inni badacze wieszcza $z$ kolei rozpad strefy euro lub przynajmniej „unarodowienie” wspólnej waluty. Wszystkie te sygnały wskazuja na spowolnienie lub zatrzymanie się politycznej integracji zawartej w traktacie lizbońskim. 
się w zglobalizowanym świecie, w którym państwa i obywatelstwo przypisane do państwa nie mają już dominującego znaczenia. Nieco odmienna propozycje przedstawił Joseph H.H. Weiler w książce Chrześcijańska Europa ${ }^{12}$, w której opisał Unie jako obszar uzgodnionych i potwierdzonych prawnie lub zwyczajowo rozwiązań, które sa korzystne dla wszystkich państw członkowskich. Omija to problem braku europejskiego demosu. Jak pisze gdzie indziej: „Mogę być Niemcem w tym węższym znaczeniu silnej organiczno-kulturowej identyfikacji i poczucia przynależności. Jednocześnie jestem obywatelem europejskim $\mathrm{w}$ tym znaczeniu, że podzielam ponadnarodowe podobieństwa, wybierając te same wartości, które wyrastaja ponad różnice etniczno-narodowe. Tyle że w obrębie życia publicznego godzę się uznawać legitymację i wiążąca moc decyzji podjętych przez moich europejskich współobywateli, mając świadomość, że w tych obszarach wybrałem decyzje podjęte przez mój szerszy, a nie węższy demos"13. Mamy więc w Unii Europejskiej konstytucjonalizm bez konstytucji. Obywatelstwo wielowarstwowe, które jest zbudowane na podstawie wspólnych celów czy podzielanych wartości, a nie wspólnej kultury, języka albo więzów krwi. Mamy sytuację, w której wspólna forma prawna generuje taki poziom ogólności, że może się w niej zmieścić wiele odmiennych porządków normatywnych. Unia staje się plastycznym tworem, w którym forma jest równie ważna jak treść. Treść zaś to przede wszystkim prawa człowieka stanowiące aksjologiczny fundament Karty.

\section{Minikonkluzje}

Podsumowując dotychczasowe rozważania, można stwierdzić, że największym problemem związanym $z$ obywatelstwem - jeśli będziemy dalej szli w kierunku, jaki wyznacza Karta Praw Pod-

\footnotetext{
${ }_{12}$ J.H.H. Weiler: Chrześcijańska Europa, Konstytucyjny imperializm czy wielokulturowość?, przekład W. Michera, Wydawnictwo „W Drodze”, Poznań 2003.

${ }_{13}$ J.H.H. Weiler: Czy Europa potrzebuje konstytucji? Demos, telos i orzeczenie Niemiec w sprawie traktatu z Maastricht, „Nowa Europa” 2005, nr 1, s. 113.
} 
stawowych - jest przede wszystkim kwestia, jak Unia Europejska ma zagwarantować i chronić prawa obywatelskie tam zapisane, zwłaszcza te dotyczące ochrony mniejszości kulturowych czy uboższych ekonomicznie. Kolejnym, nie mniej istotnym problemem jest jedynie abstrakcyjny wymiar obowiązków obywateli Unii wobec tej struktury. Jak dotąd podstawa obywatelstwa sa państwa, a podstawa legitymizacji decyzji unijnych - międzyrządowe konsultacje w ramach Rady Europy i Komisji Europejskiej. Choć oczywiście należy pamiętać, że traktat lizboński zacieśnia współpracę polityczną członków Unii, zwiększa rolę Parlamentu Europejskiego, a także ustanawia stanowisko prezydenta oraz ministra do spraw zagranicznych, co docelowo ma przynieść większą spójność Unii $\mathrm{w}$ relacjach $z$ innymi podmiotami na arenie międzynarodowej.

Pojawiajacy się mimo wszystko cały szereg pytań - typu: Czy nie brakuje w Karcie oprócz praw obywatelskich również obowiązków? Czy Karta powinna funkcjonować jak amerykańska Karta Praw (Bill of Rights)? - pozostaje na razie bez odpowiedzi. Jedno chyba tylko nie ulega watpliwości. Podniesienie Karty Praw Podstawowych Unii Europejskiej do rangi obowiąującego na terenie Unii aktu prawnego będzie niewatpliwie istotnym wydarzeniem w procesie przekształceń ustrojowych Unii. 